\title{
The Relationship between Nursing Staff Communication Skills and Quality of Nursing Care in A Pediatric University Specialized Hospital
}

\author{
EMAN S. MOUSTAFA, M.Sc.; MAHSAN I. ABED-ELMEGEED, D.N.Sc. and FATMA A. ABED, D.N.Sc.
}

The Department of Nursing Administration, Faculty of Nursing, Cairo University

\begin{abstract}
Background: Studies were done all over the world related to communication skills and quality of nursing care but most of studies were done in that context based on others perspectives'. Nursing staff are the dominant hand in health care system, their skills development particularly communication skills could improve quality of care especially when dealing with children.
\end{abstract}

Aim of Study: The aim of this study is to assess the relationship between nursing staff communication skills and quality of nursing care in Pediatric University Specialized Hospital.

Subjects and Methods: A descriptive correlational design was utilized to collect data which was conducted in 4 Icu units in a Pediatric University Specialized Hospital affiliated to Cairo University Hospitals in Egypt. The sample was equated of 40 nurses of nursing staff and their assigned 40 patients who meet criteria. Data were collected through Glasgow coma scale; demographic data, medical and nursing datasheet was reviewed. It was also collected by utilized two observational checklists used in data collection were developed by the researcher. Developed tools are Communication Skills (CSOC) and quality of nursing care (QOC), these tools were validated by experts' opinions and pilot-tested. The time framework of the study was April 2018 to February 2019.

Result: The study revealed that $(67.5 \%)$ of the studied sample had unsatisfactory communication skills and (75\%) of the studied sample had unsatisfactory quality of nursing care. Also there was a highly statistically significant relation between communication skills and quality of nursing care.

Conclusion: A strong positive relationship between nursing staff communication skills and quality of nursing care in the selected pediatric hospitals is what current study resulted in.

Recommendations: The study recommended that training courses on communication skills for nursing staff should be conducted, studies should be encouraged in the field of communication in nursing career as it is an important element in quality of care.

Key Words: Communication skills - Pediatric nurse - Quality of nursing care - Nursing process.

Correspondence to: Dr. Eman S. Moustafa, The Department of Nursing Administration, Faculty of Nursing, Cairo University

\section{Introduction}

COMMUNICATION is a vital element in nursing in all areas of activity, including prevention, treatment, rehabilitation, education, and health promotion. Communication skill is a core skill for all healthcare professionals and nursing staff in particular, as nurses spend more time with patients and relatives than any other healthcare professional [1]. Nurses working in Intensive Care Units (ICU) find it especially challenging to communicate with very ill patients [2]. Communication between nurses and these patients requires specific knowledge, skill and commitment. Some studies have shown that in real-world clinical practice most of the complaints received from patients in intensive care units on health professionals are related to ineffective communication and not to the lack of clinical skills [3]. Nurse-patient communication is highly important especially when the patient is a child because childhood is one of the most important stages of development [4]. Recent studies showed that most medical errors were not really due to defect in medical technologies or negligence of healthcare providers; rather, they were absolutely related to ineffective communication between patients and healthcare providers [5]. The Joint Commission's analysis of 2012, 2013 and firstquarter 2014 data revealed that in all three time frames, communication was one of the top three leading causes of sentinel events, a patient safety event unrelated to the patient's illness or condition that results in death, permanent harm or another qualifying negative outcome [6].

\section{Significance of the study:}

Patient communication is crucial. Because the time spent at a hospital is usually stressful for patients and their families, they often tend to get impatient and angry if they feel that they are not being treated well. Also bad or ineffective commu- 
nication can take a bad situation and make it worse. It leads to problems and could even endanger a patient's life. A nurse who is good at communicating can get the message across clearly, can save a lot of time, also get a lot more information out of a patient, resulting in quicker diagnoses and more effective treatment plans. These are just some of the reasons why it is necessary for all nurses to sharpen and practice their communication skills so that they can improve. Being able to communicate well make nurses act and perform their job in a professional way which will improve their image in the community. This study will contribute in assessing nature of relationship between communications skills and quality of nursing care in selected setting in Egypt.

\section{Research questions:}

What is the relationship between nursing staff communication skills and quality of nursing care in Pediatric University Specialized Hospital?

\section{Subjects and Methods}

Research design: A descriptive correlational design was utilized for this study.

Setting: The study was conducted at a Pediatric University Specialized Hospital affiliated to Cairo University Hospitals within time frame from April 2018 to February 2019, the selected Intensive Care Units (ICU) were (third floor ICU units which contain two ICU unit; one is critical cardiac ICU and the second is cardiac rehabilitation ICU-fourth floor ICU-fifth floor ICU).

Subjects: A sample of (40) nurses (31 staff nurses, 4 charge nurses and 5 head nurses) and their assigned (40) patients who meet criteria in the selected four ICU units from all nursing staff levels working during morning shift and accept to participate. The sample was statistically equated.

\section{Inclusion and exclusion criteria:}

Inclusion criteria for nurses: Years of experience is more than 6 months-permanent nurse. Inclusion criteria for patient: Age 7-11 years-fully conscious patient which is detected through using Glasgow coma scale-at least an overnight stay in hospital. Exclusion criteria for patient: Emergency casesNeonatal cases-Patients with neurological disorders -Mental retard patient.

Tools of data collection: Data for the present study was collected by utilizing the following tools:

- 1st tool: Communication Skills Observational Checklist (CSOC) (tool 1): This tool was developed by the researcher for measuring nursing staff com- munication skills, through using the concept of caring adopting by Milton Mayer 8 major ingredients as necessary for caring in nursing (knowledge, alternating rhythms, patients, honesty, trust, humility, hope and courage) and the five 'Cs' of caring (compassion, competence, confidence, conscience and commitment) [7]. Which consists of two parts (personal data for nurses, work environment related data and communication skills).

Scoring system: Each item of communication skills observational checklist was checked by the researcher as three-point Likert scale as following: Correct (2) partially correct (1) not correct (0). The scores of each part and for the total observation checklist were converted into percent scores.

- 2nd tool quality of nursing care observational checklist (QOC) (tool 2): This tool was developed by the researcher for measuring quality of pediatric nursing care, through reviewing and adopting the model of nursing process [8] and it contain items of child care similar to [9]. This consists of (five categories include steps of nursing process (assessment, diagnosis, planning, implementation and evaluation). Five categories of nursing process measuring quality of care.

Scoring system: Each item of quality of nursing care observational checklist was checked by the researcher as three-point Likert scale to assess quality of care as following: Always (3) sometimes (2) never (1). The scores of each part and for the total observation checklist were converted into percent scores.

Validity and reliability: The developed tools were formulated and submitted to a seven experts in the field of nursing administration and quality assurance departments from the faculty of nursing cairo university and the selected hospital to assess the content validity. Reliability was assessed to confirm the validity of the tools.

Pilot study: A pilot study was conducted on in May 2018 on $10 \%$ of the sample to estimate the needed time for data collection and to test feasibility, clarity and the applicability of the study tools. And to detect any possible obstacles that might face the researcher and interfere with data collection based on the result of the pilot study. Since no changes were needed in the data collection tools. The pilot sample was included in the main study sample.

Methods of data collection: Once an official permission was obtained from the director of the hospital to proceed with the proposed study. As 
well as the director of nursing service administration. Meeting and discussion was held between the researcher and the nursing administrative personnel in each selected ICU unit to make them aware of the objectives of the research. Data collection was started by selecting participants according to the study inclusion and exclusion criteria. Then each participant was interviewed individually to make them aware of the objectives of the research, ask his/her acceptance to participate in the study, taking consent. Later collecting demographic data and work environment related data in communication skills tool. Then each participant was observed by the researcher using communication skills observational checklist according to availability of assigned patients who met the study inclusion and exclusion criteria. Each participant was interviewed individually, observed twice for two check lists and medical and nursing sheets was reviewed for about 6 months starting informal for two weeks in April 2018 until permission done and formal from May to July 2018, then in January and February 2019.

Ethical consideration: An official primary approval to conduct the proposed study was obtained from the Research Ethical Committee, Faculty of Nursing, Cairo University then an official permission was obtained from the director of Specialized Pediatric University Hospital. Participation in this study was entirely voluntary; each participant had the right to accept or refuse participation in the study. Informed consent was obtained from the study subjects. Anonymity and confidentiality are assured through coding the data, every participant had the right to withdraw from the study at any time, participants were assured that this data will not be reused in another research without permission, data collected was used in the purpose for the research only and the entire needed sample in the study was followed until been analyzed.

Statistical analysis: The collected data were scored, tabulated and statistically analyzed by computer using "Statistical Package for the Social Science (SPSS) program version 20". Descriptive statistics in the form of frequencies and percentages for qualitative variables, and means, standard deviations and medians for quantitative variables. Statistical significance was considered at $p<0.05$. Approprait statistical test were applied for data analysis.

\section{Results}

Table (1) reveals that three quarters of the sample $(75 \%)$ were females and more than half of the sample (65\%) was in the age category $21-30$ and married (57\%). Also more than the third (42\%) had diploma education while $30 \%$ had Bachelor degree. More than half (57\%) had 1-10 years of experience and more than the third (35\%) worked in El-Nagar Unit while more than three quarters (77.5\%) worked in medical unit and $45 \%$ long shift with more than half of the sample (57\%) worked 2-3 shifts. Table (2): Reveals that the majority of the studied sample $(67.5 \%)$ had unsatisfactory communication skills while only $32.5 \%$ had satisfactory level. Table (3) reveals that the majority of the studied sample (75\%) had unsatisfactory quality of nursing care while only $25 \%$ had satisfactory level. Table (4) reveals that there is a highly statistically significant relation between communication skills and quality of nursing care. All those with unsatisfactory communication skills had unsatisfactory quality while the majority of those with satisfactory skills had satisfactory quality.

Table (1): Socio-demographic data and work related data of studied sample $(n=40)$.

\begin{tabular}{|c|c|c|}
\hline Items & No. & $\%$ \\
\hline $\begin{array}{l}\text { Gender: } \\
\text { Female } \\
\text { Male }\end{array}$ & $\begin{array}{l}30 \\
10\end{array}$ & $\begin{array}{l}75.0 \\
25.0\end{array}$ \\
\hline $\begin{array}{l}\text { Age }(\text { years }): \\
21-30 \\
31-40 \\
>40 \\
\text { Mean }=31.6, \mathrm{SD}=9.7\end{array}$ & $\begin{array}{l}26 \\
6 \\
8\end{array}$ & $\begin{array}{l}65.0 \\
15.0 \\
20.0\end{array}$ \\
\hline $\begin{array}{l}\text { Marital status: } \\
\text { Single } \\
\text { Married }\end{array}$ & $\begin{array}{l}17 \\
23\end{array}$ & $\begin{array}{l}42.5 \\
57.5\end{array}$ \\
\hline $\begin{array}{l}\text { Education: } \\
\text { Diploma } \\
\text { Technical Institute of Nursing } \\
\text { Bachelor degree in nursing }\end{array}$ & $\begin{array}{l}17 \\
11 \\
12\end{array}$ & $\begin{array}{l}42.5 \\
27.5 \\
30.0\end{array}$ \\
\hline $\begin{array}{l}\text { Experience (years): } \\
\quad 1-10 \\
11-20 \\
>20 \\
\text { Mean }=11.6, \mathrm{SD}=10.3\end{array}$ & $\begin{array}{l}23 \\
9 \\
8\end{array}$ & $\begin{array}{l}57.5 \\
22.5 \\
20.0\end{array}$ \\
\hline $\begin{array}{l}\text { Unit name: } \\
\text { El-Naggar ICU } \\
\text { Intensive \& Intermediate ICU } \\
\text { Cardiac ICU } \\
\text { Cardiac rehabitation }\end{array}$ & $\begin{array}{l}14 \\
13 \\
9 \\
4\end{array}$ & $\begin{array}{l}35 \\
32.5 \\
22.5 \\
10\end{array}$ \\
\hline $\begin{array}{l}\text { Unit type: } \\
\text { Surgical } \\
\text { Medical }\end{array}$ & $\begin{array}{l}13 \\
27\end{array}$ & $\begin{array}{l}32.5 \\
77.5\end{array}$ \\
\hline $\begin{array}{l}\text { Type of shift: } \\
\text { Morning } \\
\text { Mix } \\
24 \text { hours } \\
\text { Long }\end{array}$ & $\begin{array}{l}8 \\
9 \\
5 \\
18\end{array}$ & $\begin{array}{l}20.0 \\
22.5 \\
12.5 \\
45.0\end{array}$ \\
\hline $\begin{array}{l}\text { Number of shifts/week: } \\
2-3 \\
4-5 \\
6-7 \\
\text { Mean }=3.7, \mathrm{SD}=1.3\end{array}$ & $\begin{array}{l}23 \\
13 \\
4\end{array}$ & $\begin{array}{l}57.5 \\
32.5 \\
10.0\end{array}$ \\
\hline
\end{tabular}


Table (2): Levels of communication skills among studied sample.

\begin{tabular}{lcc}
\hline Levels & No. & $\%$ \\
\hline Unsatisfactory $(<50 \%)$ & 27 & 67.5 \\
Satisfactory $(>50 \%)$ & 13 & 32.5 \\
\hline
\end{tabular}

Table (3): Levels of quality of nursing care among studied sample.

\begin{tabular}{lcc}
\hline Levels & No. & $\%$ \\
\hline Unsatisfactory $(<50 \%)$ & 30 & 75.0 \\
Satisfactory $(>50 \%)$ & 10 & 25.0 \\
\hline
\end{tabular}

Table (4): Relation between level of communication skills and level of quality of nursing care.

\begin{tabular}{|c|c|c|c|c|c|}
\hline \multirow{3}{*}{$\begin{array}{l}\text { Communication } \\
\text { skills }\end{array}$} & \multicolumn{3}{|c|}{ Quality of nursing care } & \multirow{3}{*}{$\begin{array}{c}\text { Chi } \\
\text { square }\end{array}$} & \multirow{3}{*}{$\begin{array}{c}p- \\
\text { value }\end{array}$} \\
\hline & \multicolumn{3}{|c|}{ Unsatisfactory Satisfactory } & & \\
\hline & No. & $\%$ No. & $\%$ & & \\
\hline Unsatisfactory & 27 & 100.00 & 0.0 & 27.6 & $0.0001 *$ \\
\hline Satisfactory & 3 & $23.1 \quad 10$ & 76.9 & & \\
\hline
\end{tabular}

\section{Discussion}

The aim of this study was to assess the relationship between nursing staff communication skills and quality of nursing care in Pediatric University Specialized Hospital. This study was conducted in four ICU units and a sample of 40 nurses (31 staff nurses, 4 charge nurses and 5 head nurses) were involved randomized. Regarding to the results of demographics of sample $(75 \%)$ of nurses are female, $(30 \%)$ have bachelor degree which consistence with other study [10]

In this study nurses are observed to detect their communication skills with patients based on two concepts. The study results of levels of communication skills among studied sample show that the majority of the studied sample had unsatisfactory communication skills while only third of them had satisfactory level. As it shows that nursing staff have poor communication skills, which differ from results of other studies [10-12] as these studies reveals that nurses have high level of communication. And agree with an Indonesian study [13], as resulted that nurses have low level of communication. The investigator observations that low level of nursing staff communication skill might be due to lack of knowledge, the gap in the application of theory in actual clinical practice, unavailable and unapplied policies, procedures and job description and unavailability of systematic organization among disciplines.
As a whole after measuring quality of nursing care among studied sample. The study reveals that levels of quality of nursing care among studied sample the majority of the studied sample had unsatisfactory quality of nursing care about $75 \%$ while only quarter of studied sample had satisfactory level. This result is similar to results of other studies [14-16], but it was from nurses' perspectives and it showed that, $93.0 \%$ of nurses have no sufficient qualified nurses in the nursing process. But the current study results are unlike results in a Brazilian study in a Pediatric Hospital [17,18].

Showing relation between level of communication skills and level of quality of nursing care. The study reveals that there is a highly statistically significant relation between communication skills and quality of nursing care. All those with satisfactory and unsatisfactory levels as unsatisfactory communication skills had unsatisfactory quality while the majority of those with satisfactory skills had satisfactory quality which answer the question of the current research that nursing staff communication skills could impact quality of nursing care in the selected setting. In congruence with what said by [19] that resulted that delivering care, communicating with patients and family caregivers, as nurses spent time in communicating with patients and effort is done in order to drive quality of care which mentioned that relation between nurse communication skills and efforts to drive quality care is positive. Also it agree [20] who mentioned that communication skills can affect the quality of care and also recommended that managers should consider effective communication training to provide quality of care.

\section{Conclusion:}

A strong positive relationship between nursing staff communication skills and quality of nursing care in the selected pediatric hospitals is what current study resulted in.

\section{Recommendations:}

Training courses on communication skills for nursing staff should be conducted in order to improve their way dealing with patients, also improve their exchange of patient related information, better dealing with patient health situations, better care provided, which finally makes patient satisfied, nurses have self-esteem and providing quality nursing care. Nurses should try more gaining patients and family trust by being more skillful and showing advocacy for patient and family. Also give family hopeful information about their children conditions. It is important to involve nursing staff in educational programs in the application of the- 
oretical framework of nursing process in clinical situations, to achieve quality of care; also for continuous staff development. Encouragement of conducting studies in the context of nursing communication skills using large scale and number of patients also considering all shifts. Also adopting studies for nursing communication with physicians, technicians, workers and others.

\section{References}

1- KOURKOUTA L. and PAPATHANASIOU I.: Communication in nursing practice. Mater Sociomed, 26 (1): 657. http://dx.doi.org/10.5455/msm.2014.26.65-67, 2014.

2- AYUSO-MURILLO D., COLOMER-SANCHEZ A. and HERRERA-PECO I.: Communication skills in ICU and adult hospitalisation unit of nursing staff. Enferm Intensiva, 28 (3): 105-13, 2017.

3- ARNOLD R.M., BACK A.L., BARNATO A.E., PRENDERGAST T.J., EMLET L.L., KARPOV I. and NELSON J.E.: The critical care communication project: Improving fellows' communication skills, 2015

4- HOCHENBERRY M.J. and WILSON D.: Wong's Nursing Care of Infants and Children, ${ }^{\text {th }}$ edition. St. Louis: Mosby, 2008.

5- XIE J., DING S., WANG C. and LIU A.: An evaluation of nursing students' communication ability during practical clinical training. Nurse Education Today, 33 (8): 823-7, 2013.

6- BRIAN NEESE: Diversity Nursing Blog Effective Communication in Nursing: Theory and Best Practices, 2016.

7- MAYER OFF M.: On Caring. New York: Harper and Row Publishers, https://jaimesorianorn.wordpress.com/ comprehensive-exam, 1971.

8- DAVID STONEHOUSE: Understanding the nursing process, British Journal of Healthcare Assistants, Vol. 11, No. 8, 9 Aug., https://doi.org/10.12968/bjha.2017.11.8.388, 2017.

9- TIINIA PELANDER, HELENA LEINO KILIPI and JOUKO KATA JISTO: The quality of pediatric nursing care: Developing the child care quality at hospital instrument for children, 2008.
10- MOHAMMAD ALI MOROWATI SHARIFABAD, MOJTABA FATTAHI ARDAKANI, MOHAMMAD AMIN BAHRAMI2 and HOSSEIN FALLAHZADE: Nurses' communication skills and the quality of inpatient services from patients' viewpoints, 2019.

11- REZAEI R., HOSSEINI S.J. and VALERIE N.: Communication skills of doctors and Rush KI, Robey-Williams C, Patton LM, Chamberlain D, Bendyk H, Sparks T. 2008, Patient falls: Acute care nurses' experiences. J. Clin. Nurs., 18: 357-65. [PubMed: 18647196], 2008.

12- SUTKIN, JOHN H. LITTLEFIELD and DOUGLAS W. LAUBE: Nursing staff assessment of residents' professionalism and communication skills, Blackwell Publishing Ltd 2009. Medical Education, 43: 1081-117, 2009.

13- BUDIWAN V. and EFENDI: The Understanding of Indonesian Patients of Hospital Service Quality in Singapore. Procedia-Social and Behavioral Sciences, 224: 176-83, 2016.

14- ABATE Y. and TANGUTE D.: Quality of nursing care and nurses working environment in Ethiopia, 2019.

15- JULIANA S., ANA E. and MARIANA R.: Quality of nursing care and satisfaction of patients attended at teaching hospital, 2014.

16- ABDELKADER F. and WALAA N.E. OTHMAN: Factors Affecting Implementation of Nursing Process: Nurses' Perspective, 2017.

17- FERNANDA D., SANTOS ALVESA and EDINÊIS De BRITO GUIRARDELLOA: Nursing work environment, patient safety and quality of care in pediatric hospital, 2016

18- MOHAMED A., ATTALLH, AYMN M. HEMDAN, MOHAMED MALSAYED and AHMED ABOSHAIGAH: Patient satisfaction with the quality of nursing care provided, 2013

19- Sara Heath, October 08: Communication Key for Patient Data Sharing, Quality Improvement, https:// patientengagementhit.com/news/communication-key-for-patientdata-sharing-quality-improvement, 2019.

20- KARIMI MOONAGHI HOSSEIN and MEHRI YAVARI The Effect of Communication Skills Training on the Quality of Nursing Care of Patients, Mashhad University of Medical Sciences, 2012. 


\section{العلاقة بين مهارات التواصل لهيئة التمريض وجودة الرعاية التمريضية

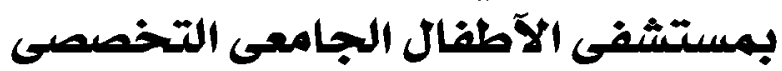

آجريت دراسات في جميع آنحاء العالم تتعلق بمهارات التواصل وجودة الرعاية التمريضية، لكن معظم الدراسات آجريت في هذا السياق التهاق

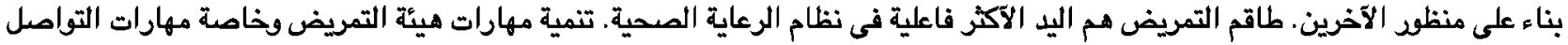
يمكن آن تصسن جودة الرعاية التمريضية خاصة عند التمريض التعامل مع الآطفال.

الهدف: هدف هذه الرسالة هو تقييم العلاقة بين مهارات التواصل لهيئة التمريض وجودة الرعاية التمريضية بمستشفى الآطفال الجامعى

$$
\text { التصميم: تصميم هذه الرسالة هو وصفى ترابطى. }
$$

العينة: عبارة عن عينة من •ع فرد من هيئة التمريض و.ع حالة المسنولين عنهم.

الموقع: لقد آجريت الرسالة بمستشفى الآطفال الجامعى التخصصى التابعة لمستشفيات جامعة القاهرة وفذارة الصحة.

الآساليب: إثثين من قوائم الملاحظة تم إنثائها بواسطة الباحث وهم كالتالى قائمة ملاحظة مهارات التواصل لهيئة التمريض وقائمة ملاحظة

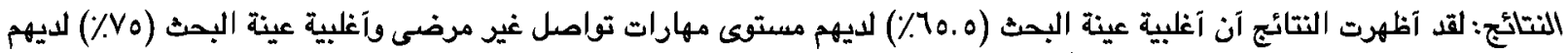
مستوى جودة رعاية تمريضية غير مرضى. آيضاً يوجد علاقة إحصائية عالية بين مهارات التقاصل لهائل الهيئة التمريض وجودة الرعاية التمريضية. الملخص: يوجد علاقة إيجابية قوية بين مهارات التواصل لهيئة التمريض وجودة الرعاية التمريضية فى مستشفى الآطفال الجامعى 